\title{
ASystematic Review to Comprehend the Cultural Representation in L2 Mandarin Textbooks
}

\author{
Wenyue Lin ${ }^{1}$, Lay Hoon Ang ${ }^{*}$, Mei Yuit Chan² and Shamala Paramasivam² \\ ${ }^{1}$ Department of Foreign Languages, Faculty of Modern Languages and Communication, Universiti Putra \\ Malaysia, 43400 Serdang, Selangor, Malaysia \\ ${ }^{2}$ Department of English Language, Faculty of Modern Languages and Communication, Universiti Putra \\ Malaysia, 43400 Serdang, Selangor, Malaysia
}

\begin{abstract}
Cultural representation in foreign/second language textbooks has received considerable research attention in recent years. This diachronic study reviews previous studies' methodological trends and research foci on cultural representation in L2 Mandarin textbooks from 2005-2020. It systematically searched all relevant publications in three accessible databases: Web of Science, Scopus, and CNKI. A total number of 48 relevant publications were collected and analyzed. The review indicates that most publications are empirical studies, covering qualitative, quantitative, and mixed studies and most sampled textbooks are elementary textbooks from China. It also reveals that the main source for collecting data is documented, and the commonly used data analysis methods are comparative, content, discourse, and semiotic analysis. Besides that, examining cultural elements in textbooks seems to be a key research focus among the publications, followed by analyzing cultural orientation, unconventional culture phenomenon, and ideology behind cultural representation in textbooks. The current study contributes to the literature by providing a detailed review of cultural representation in L2 Mandarin textbooks and identifying

ARTICLE INFO

Article history:

Received: 13 April 2021

Accepted: 10 September 2021

Published: 10 December 2021 the research gaps. Accordingly, it concludes with recommendations for future research to study cultural representation in textbooks.
\end{abstract}

DOI: https://doi.org/10.47836/pjssh.29.4.30

$\overline{\text { E-mail addresses: }}$

charlene.lin15@gmail.com (Wenyue Lin)

hlang@upm.edu.my (Lay Hoon Ang)

cmy@upm.edu.my (Mei Yuit Chan)

shamala@upm.edu.my (Shamala Paramasivam)

* Corresponding author 


\section{INTRODUCTION}

Language and culture are closely related. Language is the carrier and part of a culture, while culture is the base of language (Shu \& Zhuang, 2008). Culture plays an important role in foreign/second language (FL/L2) education since the shift in the field away from a grammar-translation approach to the development of communicative competence (Bewley, 2018). Scholars have also acknowledged the important role of culture in teaching Mandarin as a FL/L2 since the early 1980s (X. Li \& Zang, 2013). As Z. Zhang (1984) and Chen (1992) state, teaching culture is necessary for teaching language, especially the cultural knowledge relevant to language. The importance of teaching culture is also highlighted in the International Curriculum for Chinese Language Education (ICCLE), compiled by Hanban ${ }^{1}$ to guide international Chinese teaching practice. ICCLE officially stated that cultural competence is one of the elements of cultivating the L2 Mandarin learners' comprehensive language application ability. Cultural competence refers to "the ability to understand, communicate with and effectively interact with people across cultures" (Make It Our Business, 2017, para. 7). Based on ICCLE, it comprises four components: cultural knowledge, cultural understanding, intercultural competence, and international perspective (Hanban, 2014). The statement of cultural competence

\footnotetext{
${ }^{1}$ Hanban is a public institution affiliated with the Chinese Ministry of Education to provide Chinese language and cultural teaching resources and services worldwide. http://www.hanban.org/
}

established teaching culture's significant status in L2 Mandarin instruction.

With the emphasis on the teaching culture and cultivation of cultural competence, many scholars (for example, Chan et al., 2018; Hao, 2020; Huang, 2014; X. Lu \& Cheng, 2018; D. Wang, 2016) study cultural representation in L2 Mandarin textbooks, since textbooks are the major source of language and culture input in classroom teaching and may influence both learners' and instructors' experiences. These studies document scholars' contributions to literature and shape our understanding of cultural representation in L2 Mandarin textbooks. However, little work has been done to identify the gaps in methodological developments and research focus. As Shen (2019) states, there is a need for a systematic review of the current state of the literature in cultural representation in textbooks. Such a review may help to visualize the current status and distribution of the most researched focus and methodology, show readers about the latest advancements and further research directions in research. Hence, this paper aimed to review the studies of cultural representations in L2 Mandarin textbooks from 2005 to 2020. The cultural representation in this paper refers to the various cultures represented in textbooks, while culture is "ideas, customs, skills, arts, and tools that characterize a given group of people" (Brown, 2000, p. 177). As Newmark (1988) proposes, culture can be identified from the following five domains: ecology (flora, fauna), material context (food, clothes, house, transport), 
social context (work or leisure), social organizations (political and administrative, religious, artistic), and gestures and habits. The following research questions will guide this systematic review:

(1) What are the methodological trends of the studies on cultural representation in L2 Mandarin textbooks?

(2) What are the foci of the studies on cultural representation in L2 Mandarin textbooks?

\section{METHODOLOGY}

The present study was a diachronic study that performed a systematic review on methodological trends and research foci in the studies of cultural representations in L2 Mandarin textbooks (2005-2020). It followed the PRISMA framework of Liberati et al. (2009).

\section{Database Selection}

A systematic search was conducted utilizing the following electronic databases: China National Knowledge Infrastructure (CNKI), Web of Science (WoS), and Scopus (Figure 1). CNKI is "the largest academic Chinese journal full-text database worldwide covering various disciplinary studies" (M. Li, 2020, p. 41). It was selected as the studies of cultural representation in L2 Mandarin textbooks are rich in this database. WoS and Scopus were selected as neither is inclusive but complements each other (Burnham, 2006). The former is regarded as the most comprehensive database covering most peer-reviewed journals in social sciences (Steinhardt et al., 2017).

\section{Study Selection}

The review developed a query utilizing particular key terms to fulfill the research questions of the present study. It focused on previous studies of cultural representation in L2 Mandarin textbooks in CNKI, WoS, and Scopus during the period 2005-2020 because the year 2005 witnessed a significant event, the First World Chinese Congress, marking the beginning point of promoting the teaching and learning of Chinese language globally (Ma et al., 2017). Therefore, 2005 was selected as the starting year since the studies of cultural representation in L2 Mandarin textbooks were sporadic, and most relevant studies were published after 2005. This review utilized the advanced search strategy in the database to retrieve the relevant literature on cultural representation in L2 Mandarin textbooks. It used the query '(“文化, culture/cultural representation/ representation of culture”) AND (“汉语 OR 华语, Chinese OR Mandarin”) AND (““ 教材, textbooks").' Figure 1 illustrates the flow diagram of the study selection.

\section{Eligibility Criteria}

This review focused on cultural representations in L2 Mandarin textbooks by including all studies that met the criteria presented in Table 1. A total number of 715 records of studies were initially collected. After excluding duplicate studies, this review excluded studies based on the exclusion criteria (Table 1). Similarly, this review included a study if it fulfilled the inclusion criteria (Table 1). This review mainly focused on journals, conferences, 


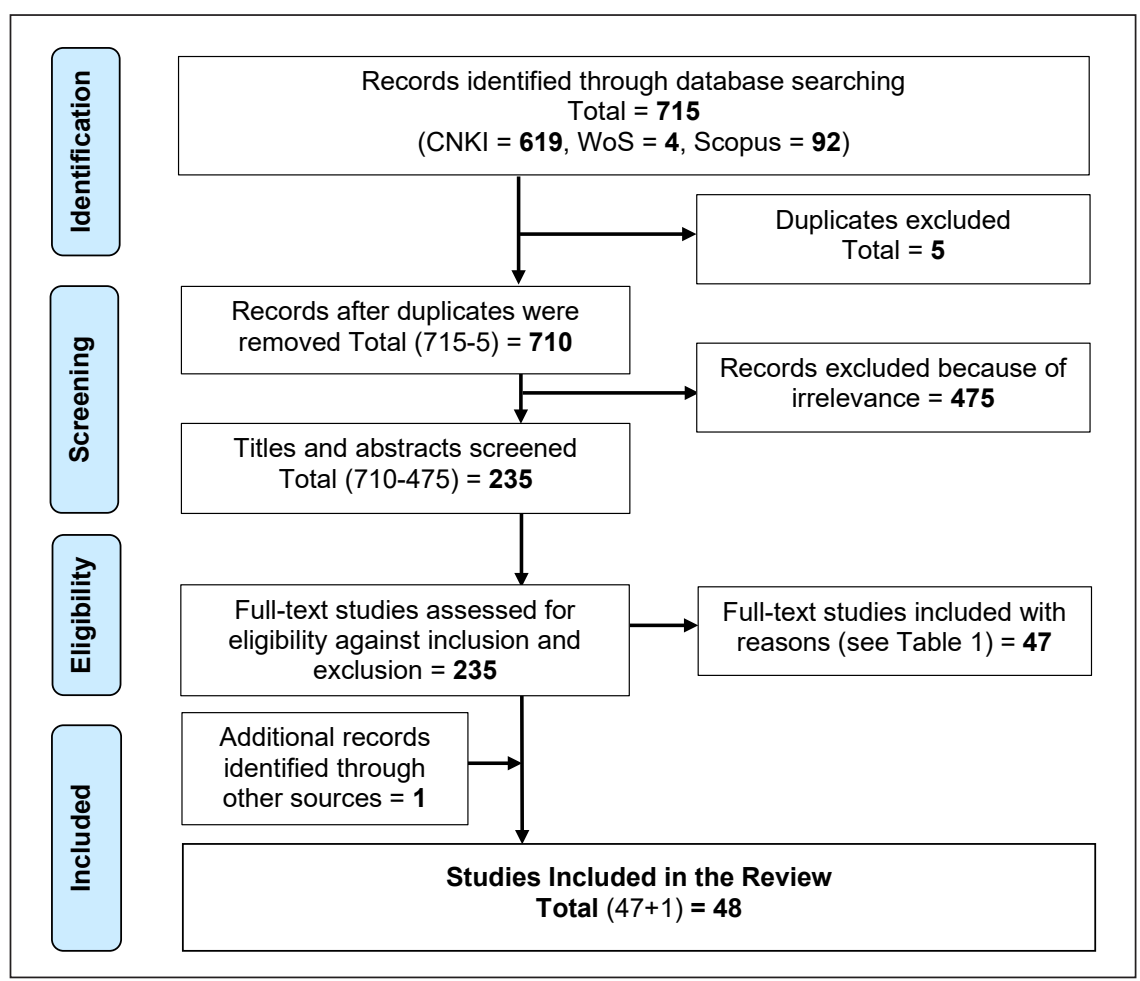

Figure 1. Flow diagram of study selection process adapted from PRISMA (Liberati et al., 2009)

Table 1

Inclusion and exclusion eligibility criteria

\begin{tabular}{ll}
\hline \multicolumn{1}{c}{ Criteria } & \multicolumn{1}{c}{ Specified criteria } \\
\hline Inclusion & 1) Studies relevant to cultural representation in L2 Mandarin textbooks \\
& 2) Journal papers \\
3) Conference papers and proceedings \\
Exclusion & 1) Unrelated studies \\
& 2) Thesis, books, and book chapters \\
& 3) The full-text study is not available online \\
4) Studies that do not focus on cultural representation in L2 Mandarin textbooks
\end{tabular}

and proceeding papers because they were subject to rigorous review. Consequently, 48 records of studies were identified as relevant between 2005-2020 (Figure 1).

\section{Inter-rater Reliability}

After searching CNKI, WoS, and Scopus databases, two different reviewers who are both academic researchers independently examined the obtained set of studies by title, abstract, keywords, and, if necessary, by full text to exclude studies that did not meet the eligibility criteria. Cohen's Kappa was utilized to test the inter-rater reliability between the choices made by the two independent reviewers in selecting studies. 
The obtained inter-rater reliability value of $\mathrm{K}$ was equal to 0.89 , which indicates a good agreement between the two reviewers (Landis \& Koch, 1977).

\section{Data Extraction and Analysis}

The 48 collected studies were imported into ATLAS.ti (9th version) software in which coding can be done by simply dragging codes onto the selected piece of data, and findings can be linked in a semantically meaningful way ${ }^{2}$. Then, each study was reviewed, examined, and coded in ATLAS. ti based on two items, as listed in Table 2. These items provide information to address the research questions mentioned above and to conduct the synthesis.

The analysis of methodological trends started with examining the title, abstract and methodological sections concerning research method, sample selection, data collection procedures, and data analysis methods. Drawing on a categorization procedure adopted by Gao et al. (2001) and M. Li (2020), this study then categorized all collected studies into empirical and nonempirical studies. An empirical study was based on whether its data was systematically collected and analyzed (M. Li, 2020). The empirical studies were further divided into qualitative, quantitative, and mixed (using

\footnotetext{
$\overline{2}$ https://atlasti.com/product/what-is-atlas-ti/
}

Table 2

Items used for analyzing the collected studies qualitative and quantitative methods) studies. A qualitative method is seen as a data-driven study that applies systematic data collection and analysis techniques (Henning, 1986), such as text analysis and narrative accounts (M. Li, 2020). A quantitative method is characterized by its quantification of data, which relates to research design, several independent variables, and statistical analysis (Henning, 1986; M. Li, 2020). In general, the nonempirical studies discuss theory and application or introduce personal views and experience "without substantial literature review, purposeful research planning, details of operational procedure and solid data" (Gao et al., 2001, p. 3). After categorizing empirical and non-empirical studies, this study then extracted and analyzed the information of sample selection, data collection, and analysis methods of both types of study.

On the rare occasions when the two reviewers were unable to reach a consensus on what methodology and which research topic a study should be categorized under, they followed the category decided based on discussion.

\section{RESULTS AND DISCUSSION}

This section presents and discusses the results of the collected studies on cultural representations in L2 Mandarin textbooks.

\begin{tabular}{ll}
\hline Items & Description \\
\hline Methodologies & $\begin{array}{l}\text { Description of the research methodology of the study, including research methods, } \\
\text { sample selection, data collection, and data analysis methods }\end{array}$ \\
Research foci & Description of the research focus of the study \\
\hline
\end{tabular}


Figure 2 shows the distribution of the 48 collected studies between 2005-2020. Cultural representation in the textbooks is an issue with a continuous concern in L2 Mandarin education. The findings of methodological trends and research foci are presented in the following.

\section{Methodological Trends}

The methodological research trend was analyzed to identify whether there are any new developments in research methodology. It focuses on four aspects: research method, sample selection, data collection, and data analysis.
Research Method. With respect to the research methods of collected studies $(\mathrm{N}=48)$, there are both empirical studies $(\mathrm{N}=39)$ and non-empirical studies $(\mathrm{N}=9)$ concerning cultural representations in L2 Mandarin textbooks. However. unlike the finding reported in Li's (2020) systematic review of research on Chinese character teaching and learning, most publications on cultural representation in L2 Mandarin textbooks are empirical studies. Thus, it seems that there is a trend for empirical study overall, especially in the year 20162020 (Figure 3).

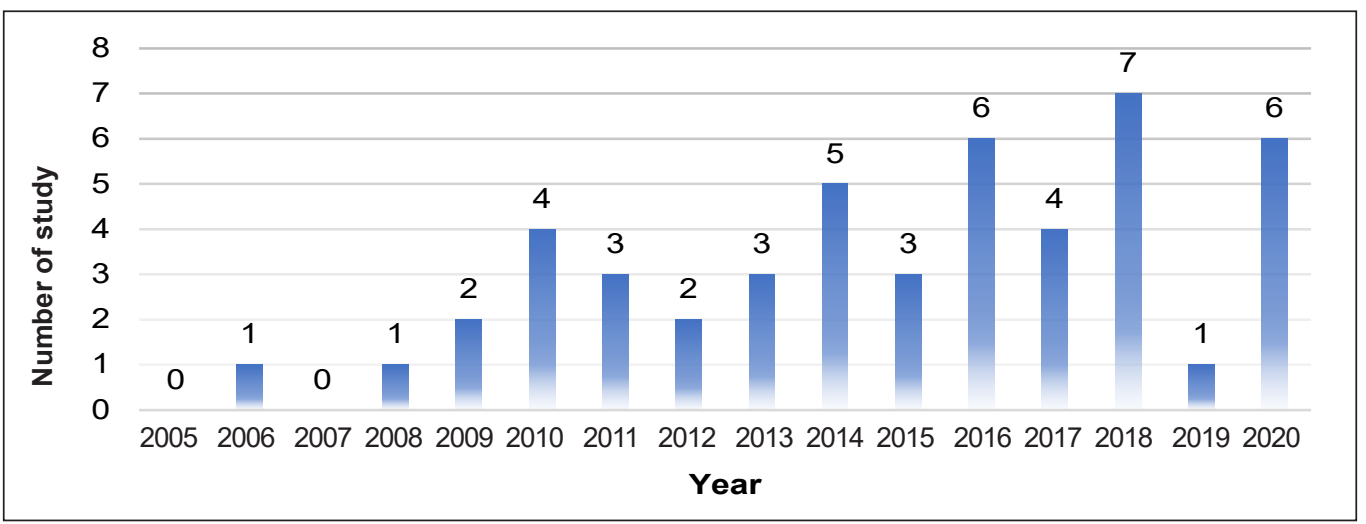

Figure 2. Distribution of relevant studies between 2005-2020

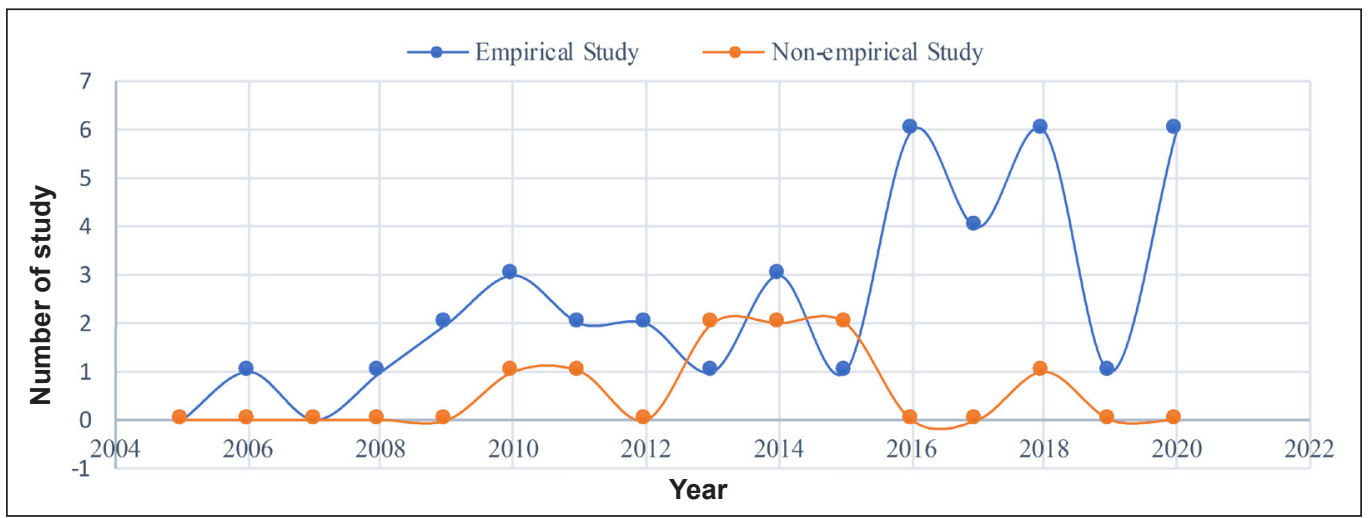

Figure 3. Distribution of research methods of previous studies (2005-2020, N=48) 
Among the empirical studies, most of them are qualitative study $(\mathrm{N}=18)$, followed by quantitative study $(\mathrm{N}=16)$ and mixed study $(\mathrm{N}=5)$. The qualitative studies generally analyze how the culture is presented and examine whether and to what extent culture is valued. The mixed studies also investigate the views or attitudes of teachers or learners towards the cultural representations in textbooks. Figure 4 shows the distribution of the three kinds of studies from 2005 to 2020 .

Sample Selection. Based on the description of textbooks sampled in collected studies, sample selection was analyzed in this review, covering the countries/regions where the sampled textbooks come from and the levels of sampled textbooks (Tables 3 and 4).

Table 3 shows that most of the collected studies analyze cultural representation in the textbooks from a certain country/region. The most frequently sampled textbooks are from China, followed by America, England, Korea, Japan, Hongkong, Taiwan, France, Italy, Thailand, Malaysia, and Finland. Thus, analyzing cultural representation in the textbooks from China and other countries/ regions is helpful to understand the overall situation of cultural representations in L2 Mandarin textbooks in the world.

Table 4 shows that the collected studies mainly focus on the textbooks written for learners at the elementary level of Mandarin, followed by intermediate and advanced levels. However, a few of them focus on cultural representation in all three levels of textbooks. The result reveals that intermediate and advanced language textbooks and elementary textbooks can integrate cultural knowledge for developing learners' cultural competence (Z. Zhang, 1990). Hence, a comprehensive investigation of textbooks at different levels may be conducive to understanding cultural representation in textbooks.

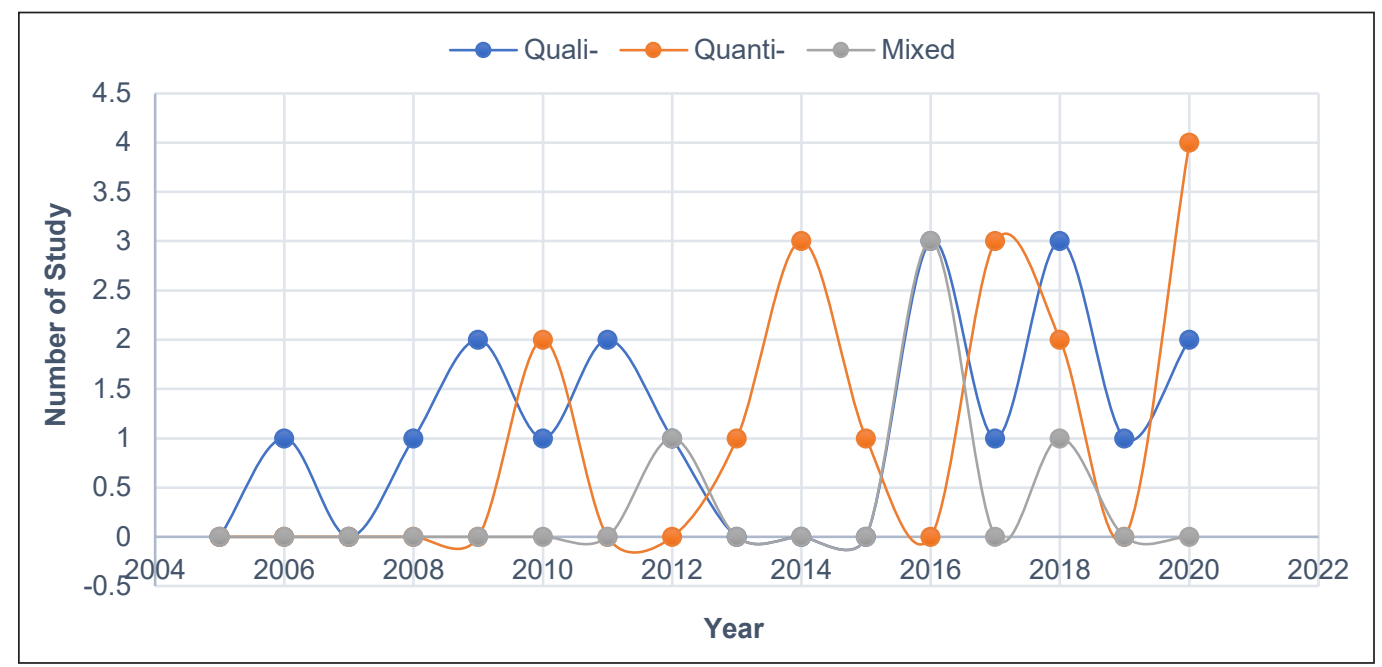

Figure 4. Distribution of qualitative, quantitative, and mixed studies (2005-2020, N=39) 
Table 3

Distribution of country/region of sampled textbooks in collected studies

\begin{tabular}{|c|c|c|c|c|}
\hline \multirow{2}{*}{$\begin{array}{l} \\
\text { Empirical }\end{array}$} & \multirow[b]{2}{*}{ Comparative } & \multirow{2}{*}{$\begin{array}{r}\text { Country/Region } \\
\text { China \& America }\end{array}$} & \multicolumn{2}{|c|}{ Number of study } \\
\hline & & & 3 & 8 \\
\hline \multirow[t]{13}{*}{ Study } & Study & China \& America \& Japan & 1 & \\
\hline & & China \& Italy & 1 & \\
\hline & & China \& Korea & 1 & \\
\hline & & China \& Hongkong \& Taiwan & 1 & \\
\hline & & $\begin{array}{l}\text { America \& England \& Italy \& Japan \& } \\
\text { Korea \& Thailand }\end{array}$ & 1 & \\
\hline & Non-comparative & China & 20 & 31 \\
\hline & Study & Hongkong & 1 & \\
\hline & & England & 2 & \\
\hline & & France & 2 & \\
\hline & & America & 2 & \\
\hline & & Malaysia & 2 & \\
\hline & & Korea & 1 & \\
\hline & & Thailand & 1 & \\
\hline Non-empirical & & China & 2 & 9 \\
\hline \multirow[t]{2}{*}{ Study } & & Finland & 1 & \\
\hline & & Uncertain & 6 & \\
\hline Total & & & & 48 \\
\hline
\end{tabular}

Note. Uncertain means that the study does not provide exact information on which country/region the sampled textbook is from.

Table 4

Distribution of levels of sampled textbooks in collected studies

\begin{tabular}{llc}
\hline & \multicolumn{1}{c}{ Level } & Number of study \\
\hline Empirical Study & Elementary & 13 \\
& Intermediate & 5 \\
& Advanced & 1 \\
& Elementary + Intermediate & 3 \\
& Elementary + Intermediate + Advanced & \multicolumn{2}{c}{5} \\
& Intermediate + Advanced & \multicolumn{2}{c}{1} \\
& Uncertain & 11 \\
Non-empirical Study & Elementary & \multicolumn{2}{|c}{1} \\
& Intermediate & \multicolumn{2}{|c}{1} \\
& Elementary + Intermediate & 1 \\
& Elementary + Intermediate + Advanced & \multicolumn{2}{c}{1} \\
Total & Uncertain & 5 \\
\hline
\end{tabular}

Note. Uncertain means that the study does not provide an exact description of the sampled textbooks' level.

Data Collection. Both empirical and non- also collect data through questionnaires and empirical studies mainly collected data interviews with L2 Mandarin learners and through the document (textbooks; Table 5). teachers (Ge, 2016; X. Li, 2014). It is worth Except for documents, the empirical studies noting that some empirical studies also pay 
Table 5

Data collection of collected studies

\begin{tabular}{llc}
\hline & \multicolumn{1}{c}{ Data collection } & Number of study \\
\hline Empirical studies & Document & 34 \\
& Document + Questionnaire (S) & 1 \\
& Document + Interview (S) + Questionnaire (S) & 1 \\
& Document + Interview (T) + Questionnaire (S) & 2 \\
& Video & 1 \\
Non-empirical studies & Document & 4 \\
& No specific data source & 5 \\
\hline
\end{tabular}

Note. S refers to learners, T refers to teachers.

attention to the cultural representations in video materials (Y. Wang, 2016). It suggests that a multi-pile source for collecting data can also be an option in studying cultural representation in textbooks.

Data Analysis Method. The present study finds that no specific data analysis methods are reported in the nine non-empirical studies. The most used data analysis methods of the 39 empirical studies are comparative analysis, content analysis, discourse analysis, and semiotic analysis. The result is similar to Weninger and Kiss's (2015) study on analyzing culture in foreign/ second language textbooks. A comparative analysis compares cultural representation in textbooks from different countries/ regions (for example, Zhen, 2018). Content analysis is usually used to investigate cultural information presented in textbooks' topics, words, and illustrations (Chan et al., 2018; Lin et al., 2020; Ouyang, 2020; Ouyang \& Zhou, 2016). It has also been used to sketch out the aspects of national identity that are integrated into textbooks (D. Wang, 2016). Discourse analysis has been employed to analyze Chinese culture's underlying dialogues in textbooks ( $\mathrm{H}$. Chen \& Yan, 2017; Ran, 2011). Finally, semiotic analysis is utilized to figure out how education-related cultural values are represented in visual images (pictures) in textbooks (Xiong \& Peng, 2020). Content analysis, discourse analysis, and semiotic analysis offer complimentary methodologies (Weninger, 2018) for exploring visual and linguistic representations of cultural meanings in textbooks.

As the results of methodological trends reveal, empirical study has dominated the previous studies of cultural representation in L2 Mandarin textbooks. Qualitative, quantitative, and mixed methods are all utilized to study cultural representation, which undoubtedly contributes to understanding the important role of teaching culture in L2 Mandarin education. However, there are some methodological gaps based on the literature. Firstly, with respect to research methods, the counting units in most quantitative studies contain the piece of reading related to culture (Shen, 2019), while many other units such as visual 
images, music, and listening materials may not be covered. Therefore, a detailed and thorough analysis of every corner of the textbooks is necessary for examining cultural information.

Secondly, in terms of sample selection, the sampled textbooks are mainly selected from China, while selecting more textbooks from other countries/regions is also worthwhile. Thirdly, for data collection, although there are some studies collecting data through questionnaires, interviews, and video materials, most previous studies collect data limited to the documentary source. Therefore, it might make the studies less comprehensive in looking at cultural representation in textbooks. In addition, it seems common for some empirical studies not to provide a detailed description of their methodology section, for instance, lacking information of data analysis method and the trustworthiness (or validity and reliability) of research, which may make their findings less trustworthy (or reliable) to a certain extent. Therefore, a more rigorous and "a more balanced and in-depth integration of quantitative and qualitative techniques" (Gao et al., 2001, p. 8), multiple data sources, and complementary analysis methods are considerable for exploring cultural representation in textbooks multimodal discourses.

\section{Research Foci}

The collected studies on cultural representation in L2 Mandarin textbooks mainly focus on cultural elements, cultural orientation, the phenomenon of unconventional culture, and the ideology behind cultural representation in textbooks. The following sections present the findings of each research focus and relevant research methodologies that are employed.

Cultural Elements in Textbooks. A total of 44 collected studies analyze cultural representation by investigating cultural elements in textbooks, including empirical and non-empirical studies. These studies can be divided into two groups: general aspect of cultural elements and specific aspect of cultural elements. The former refers to the studies which focus on various aspects of cultural elements, while the latter refers to the studies which simply focus on one aspect of cultural elements. The details are presented and discussed in the following.

\section{General Aspect of Cultural Elements.}

There are 32 studies focusing on the general aspect of cultural elements in textbooks, mostly empirical studies. Both qualitative and quantitative research approaches are employed to examine the general aspect of cultural elements in textbooks. Through applying content and comparative analysis methods, scholars analyze and compare how or to what extent the general aspect of cultural elements are represented in L2 Mandarin textbooks (Chan et al., 2018; Zhen, 2018). These studies can be divided into two sub-groups of studies. The first subgroup is the studies that examine cultural elements without employing frameworks (for example, Fan \& Sun, 2018; Y. Liu, 2017; 
Xin, 2015; J. Yang, 2014). The second subgroup is the studies that categorize cultural elements based on different frameworks (for example, Chan et al., 2018; Hao, 2020; Huang, 2014; Lin et al., 2020; X. Lu \& Cheng, 2018; S. Wang, 2013; J. Wang, 2016). The most commonly used framework $(\mathrm{N}=9)$ is proposed by Z. Zhang $(1984,1990)$ and developed by Chen $(1992,1997)$.

Z. Zhang $(1984,1990)$ categorizes culture into knowledge-culture (知识文 化, zhīshí wénhuà) and communicativeculture (交际文化, jiāojì wénhuà) from the functional perspective of culture in L2 teaching. The former refers to cultural background knowledge, which does not affect the understanding and using certain words or sentences when two people from different cultural backgrounds communicate (Z. Zhang, 1990, p. 17). In addition, it contains knowledge of literature and art, history, movies, music, beliefs, value, and the geography of a particular country. The latter refers to the cultural knowledge that directly influences the accuracy and effectiveness of communication between people from different cultural backgrounds (Z. Zhang, 1990, p. 17).

Further, Chen (1992, 1997) divided communicative-culture into three aspects: cultural elements in language structure (语构, yǔgòu), semantics (语义, yǔyi) and pragmatics (语用, y̌̌yòng). Cultural elements in language structure are embodied in vocabulary, phrases, and sentences and reflect cultural characteristics through the grammatical structure (Chen, 1992). Cultural elements in semantics are contained in lexis and idioms (Chen, 1997). They carry the Chinese's unique meaning, concept, and thoughts (Chen, 1992, 1997). This kind of cultural element may cause misunderstanding in communication if learners do not learn the cultural meaning of the lexis and idioms (Chen, 1997). Finally, cultural elements in pragmatics refer to the cultural norms or conventions in language use in the social context and interpersonal relationships (Chen, 1992, 1997). They are embodied in the speech acts of greeting, leave-taking, praise, apology, appreciation, honorific, and taboos in communication (Chan et al., 2018; Chen, 1992, 1997).

Based on the framework of Z. Zhang (1984, 1990) and Chen (1992, 1997), scholars found that there are some features of cultural elements in textbooks. On the one hand, Hao (2020) and Huang (2014) mentioned that knowledge cultural elements were presented dominantly in elementary, intermediate, and advanced textbooks. On the other hand, some scholars, such as Lin et al. (2020), S. Wang (2013), and J. Wang (2016), stated that communicative cultural elements had been emphasized in textbooks. Additionally, as Huang (2014) reports, the communicative cultural elements in semantics and pragmatics were presented explicitly in textbooks.

However, there are also some problems with selecting and presenting cultural elements in L2 Mandarin textbooks. For instance, as X. Li (2014) and S. Wang (2013) state, the selection and presentation of cultural elements in some sampled textbooks were a bit random. S. Wang (2013) indicated 
that it was probably because of the lacking cultural syllabus in L2 Mandarin education. Moreover, Huang (2014) revealed that cultural elements relevant to philosophical and religious aspects were not stressed in textbooks. Hao (2020) found that there was also a weak presentation of communicative cultural elements in textbooks, and S. Wang (2013) indicated that the presentation was unsystematic and unproperly leveled. Meanwhile, as the studies of Chan et al. (2018) and Y. Zhang (2009) reveal, these elements were implicitly presented and lack further descriptions in textbook contents. Chan et al. (2018) also indicated that linguistics skills were still the foci in mostly sampled textbooks (elementary level) from Malaysia, while cultural elements were not stressed. The problems mentioned above are not conducive to developing learners' cultural awareness and communicative competence.

These 32 studies had shed light on the general aspect of cultural elements, drawing on the features and problems of selecting and presenting cultural elements in L2 Mandarin textbooks. However, despite the fact that different categorization frameworks of cultural elements were employed in these studies, the categorization criteria are not always clear-cut, and some categories might be overlapping. This problem is also reported in Shen's (2019) review on studies of cultural contents in English textbooks. Therefore, an inclusive and analytical framework is necessary for categorizing cultural elements.
Specific Aspect of Cultural Elements. There are 12 studies focusing on specific cultural elements and mainly covering cultural words, cultural topics, traditional culture, and regional culture in textbooks. Both empirical and non-empirical studies are conducted to analyze the specific aspect of cultural elements in L2 Mandarin textbooks.

Cultural Words in Textbooks. Five studies analyzed cultural elements by examining cultural words in textbooks (Ge, 2016; Lei, 2017; X. Li, 2012; Zhao, 2010; Zhen, 2018). Cultural words related to festivals, food, clothing, idiom, history, and religions, are important for L2 learners. Zhao's (2010) quantitative study compared cultural words in four sets of textbooks (intermediate level) from China. It was stated that some textbooks might fail to pay enough attention to the compilation of cultural words, and some cultural words were too difficult for learners. Lei (2017) and Zhen (2018) also indicated that selecting and arranging the cultural words appropriately and balanced was necessary when writing textbooks. In addition, Li's (2012) qualitative study analyzed and compared the representation of cultural words in three sets of textbooks from China. It was found that most cultural words in textbooks were related to Chinese culture while few of them related to the culture of other countries in the world, which might not be beneficial for L2 learners to overcome cultural resistance and develop multicultural awareness. Moreover, Ge (2016) stated that the cultural words explicitly shown in vocabulary and notes might be easier for 
learners to understand than those hidden in the oral-knowledge part of textbooks. Whether learners can obtain the cultural words hidden in textbooks depends on how teachers teach to a large extent.

Cultural Topics in Textbooks. Four studies analyzed cultural elements by specifically examining cultural topics in textbooks, for instance, the topics related to Chinese food, clothing, being a guest, festivals, digital culture, and internet culture (Fan \& Sun, 2018; X. Li, 2014; X. Liu, 2018; H. Zhang, 2011). Most of these studies are empirical studies. For instance, $\mathrm{X}$. Liu (2018) conducted a qualitative and comparative study and found that cultural topics in elementary textbooks from China failed to fully integrate Mandarin culture compared to the textbooks from Korea. Similarly, H. Zhang's (2011) non-empirical study also found that the cultural topics in local intermediate Mandarin textbooks might lack the integration of Mandarin culture. Besides that, Li's (2014) qualitative study indicated that cultural topics in textbooks from China might not fulfill learners' interests and demands. The reason was that the topics did not pay much attention to comparing different cultures because of mono-cultural output and lack of cultural tolerance (X. Li, 2014). In a word, as Fan and Sun's (2018) qualitative study reveals, the problems, such as indiscriminate and random selection of cultural topics and uneven distribution of cultural topics, still existed in the advanced level of textbooks. Therefore, the practicability of cultural topics for learners is considerable in textbooks (Fan \& Sun, 2018; H. Zhang, 2011). The attitude of multi-culturalism was also necessary for selecting cultural topics (X. Li, 2014). Foreign and Mandarin cultural topics needed to be integrated properly in textbooks (X. Liu, 2018; H. Zhang, 2011).

Traditional Culture in Textbooks. Two studies focused on traditional culture in L2 Mandarin textbooks, including one study of traditional sports culture and one study of Confucianism and traditional culture. In terms of traditional sports culture, a nonempirical study by Y. Yang et al. (2018) indicated that it was not stressed in textbooks from China. For instance, the culture such as 太极拳 (tàijí quán, Tai Chi) appeared in textbooks, while many others such as 中国 功夫 (zhōngguó gōngfu, Chinese kung fu), 赛龙舟 (sài lóngzhōu, dragon boat race), and 抖空竹 (dǒu kōngzhú, playing diabolo), were not included (Y. Yang et al., 2018). On the other hand, Lu's (2011) qualitative study mentioned that the sampled textbook from England tried to highlight and integrate them into their Confucianism and traditional culture. For instance, learning from a young, as one of the Confucian educational thoughts, was integrated into the text of 幼 不学, 老何为? (yòu bú xué, lăo hé wéi? If the child does not learn while young, what will he be when old?; Lu, 2011). The two studies suggested that Confucianism and traditional culture were also helpful to develop cultural awareness and increase learners' interests in Mandarin learning. 
However, simply focusing on Mandarin traditional cultural elements may not be helpful to develop learners' awareness of intercultural communication.

Regional Culture in Textbooks. One study focused on regional culture in textbooks, discussing cultural elements related to a city of a particular country. X. Liu (2020) conducted a quantitative study and indicated that the presentation of Nanjing regional cultural elements is insufficient in seven sets of textbooks from China, Thailand, and Korea. Instead, there is a lot of linguistic content and practice.

The afore-mentioned studies on cultural words, cultural topics, traditional culture, and regional culture had enriched the literature. They provided an insight into a specific aspect of cultural elements in L2 Mandarin textbooks. However, most of them mainly focused on textbooks from China and few were concerned with textbooks from Hongkong, Taiwan and Korea. Therefore, their findings cannot be generalized to the textbooks from other countries/regions, which may be a gap in the literature.

The 44 collected studies have shed light on cultural elements in textbooks, which reveal the importance of teaching culture in L2 Mandarin education and provide rich information on selecting and presenting cultural elements in L2 Mandarin textbooks. However, most of these studies mainly focus on the elements of Mandarin culture in textbooks. Only a few studies provide information on other cultures in the world. It seems that teaching culture in L2 education is equivalent to teaching Mandarin culture to a certain extent, while it might ignore learners' own culture or other cultures. It could be a research gap of analyzing cultural elements in the literature. Moreover, the findings of cultural elements in the collected studies are mainly based on analyzing words, sentences, topics in textbooks. In contrast, the cultural elements presented in other sources are less highlighted. Not only language but also visual images, auditory and video materials can represent cultural meanings. It may also be a research gap in analyzing cultural elements in the literature.

\section{Cultural Orientation in Textbooks.}

Cultural orientation here means whether the orientation of the textbook content refers to the culture of the country of target language itself or the culture of other countries or human topics in common $(\mathrm{Lu}$, 2018). It contains two sub-concepts: selfreferential orientation (自指取向, zizh qǔxiàng) and other-referential orientation (他指取向, $t \bar{a}$ zh ȟ qǔ xiàng). The former means that the textbook content mainly introduces the country's culture of the target language. In contrast, the latter means that the textbook content mainly introduces the culture of other countries or has a broad global university ( $\mathrm{Lu}, 2018$ ). The two sub-concepts of cultural orientation are equal to the three types of culture (target, source, and international cultures) in L2 textbooks proposed by Cortazzi and Jin (1999). As Cortazzi and Jin (1999) indicate, textbooks may integrate three types of cultural information: target culture, source 
culture, and international cultures. Target culture refers to the culture in which the target language is used as a first language, source culture refers to the learners' own culture, and international cultures refer to cultures that are neither a source culture nor a target culture (Cortazzi \& Jin, 1999). Self-referential orientation is equivalent to the target culture, while other is equivalent to source and international cultures.

Among the collected studies, two of them focused on the cultural orientation in L2 Mandarin textbooks. Through utilizing a qualitative content analysis method, Ouyang and Zhou's study (2016) found that both the selected sampled textbooks from China and America reflected selfreferential orientation, mainly representing the culture of China. In contrast, Lu's (2018) non-empirical study indicated that the cultural orientation of the sampled textbooks from France was other-referential, mainly representing France's culture and also taking universal cultures into account. In addition, Ouyang and Zhou (2016) stated that the textbooks from China and America compared different cultures, while Lu (2018) found that those from France less emphasized this aspect.

The findings of the two studies reveal that cultural orientation (or which culture needs to be represented) in textbooks may still be controversial. On the one hand, scholars (Q. Li \& Gong, 2015; X. Liu, 2018; $\mathrm{Lu}, 2018$ ) indicated that textbooks with selfreferential orientation (target culture) could fulfill learners' demands and help them to get a better understanding of China. On the other hand, it is believed that textbooks with other-referential orientation (source culture and international cultures) can make the L2 learning easier, increase learners' interest, and enable them to be communicative effectively and appropriately in intercultural contexts (Cortazzi \& Jin, 1999; Q. Li \& Gong, 2015). What is more, both selfand other-referential orientation (target and source cultures) are necessary for a successful textbook (Dong, 2014). However, more empirical evidence is necessary for considering whether the cultural orientation of L2 Mandarin textbooks, self- or otherreferential orientation or a balance of them, is a benefit for learners and how the learners can benefit from it.

The studies above have shed light on cultural orientation in L2 Mandarin textbooks. However, their findings are limited to a small number of textbooks from China, America, and France, which cannot be generalized to the cultural orientation in textbooks from other countries/regions. Besides that, it is worth noting that source culture is commonly considered equivalent to national culture (Byram, 1997; SpencerOatey, 2012). However, most nations nowadays contain different cultural groups within their boundaries, for instance, the United States, Singapore, the U.K., and Malaysia. Hence, it might not be appropriate to regard source culture as a national culture to which the learners belong (for example, Lu, 2018). In addition, both studies collect data from textbooks themselves, while the data of which learners' and teachers' perception of cultural orientation 
in textbooks content seems to be ignored. Thus, multicultural perspective and a multidimension data collection method may be considered in future studies to fill the gaps and expand the research scope.

The Phenomenon of Unconventional Culture in Textbooks. There is one study focusing on the phenomenon of 文化违和 (wénhuà wéihé, unconventional culture) in L2 Mandarin textbooks. It discusses the phenomenon that the cultural content presented in textbooks is not based on (or conform to) its socio-cultural pattern (or what is generally done or believed) in real life (H. Chen \& Yan, 2017). For instance, in a dialogue about inviting people to dinner in a textbook, the invitee initiates the conversation, which does not conform to a socio-cultural pattern in real life of Chinese people (H. Chen \& Yan, 2017). Generally, the inviter usually initiates the conversation in the socio-cultural pattern of inviting people to dinner. Chen and Yan's (2017) qualitative study utilized a discourse analysis method to analyze written dialogues in sampled textbooks from China. It was found that the phenomenon of unconventional culture commonly existed in textbooks' content. They recommended using real corpus, explored typical sociocultural patterns, and developed audiovisual materials in compiling textbooks. Their study highlights the importance of socio-cultural patterns in presenting cultural content in textbooks. However, the discourse analysis of the phenomenon of unconventional culture in Chen and Yan's
(2017) study is limited to four examples, which may be weak support of its findings to some extent.

\section{The Ideology behind Cultural} Representation in Textbooks. One collected study is trying to analyze the ideology behind cultural representation in L2 Mandarin textbooks from China. Ideology, as Woolard (1992, 1998) defines, is dominant or subordinate "ideas, discourse, or signifying practices in the service of the struggle to acquire or maintain power" (as cited in D. Wang, 2016, p. 3). Moreover, it is a shared fundamental belief system of a social collectivity (van Dijk, 2006). Based on these understandings, the ideology behind cultural representation in textbooks may concern the dominance of a L2 and its social and cultural consequences; for instance, the orientation of representing target or source cultures and the socialpsychological issues of attitudes, awareness, and identity about the status of L2 learning and teaching in a certain context.

D. Wang (2016) utilized corpus-based and qualitative content analysis methods to explore the ideology and national identity in L2 Mandarin textbooks (intermediate level) from China. It was found that the textbooks' discourse mainly covers the contents and topics of Chinese moral and civic education, which may not be of interest to international learners. Open discourse and intercultural understanding of cultural content were recommended to be included in textbooks. To analyze the ideology behind cultural representation in textbooks, D. Wang's 
(2016) study mainly focused on ideology embedded in the language of discourse. However, the possibility of conveying ideology by visual images was less focused in D. Wang's (2016) study, which may be a gap in exploring the ideology behind cultural representations in L2 Mandarin textbooks in the literature.

As the results of research foci reveal, the collected studies on cultural representation in L2 Mandarin textbooks mainly focus on cultural elements, and few of them focus on cultural orientation, the phenomenon of unconventional culture, and ideology behind cultural representation (Figure 5). This finding is similar to Shen's (2019) study that stated that the compilation and selection of cultural contents in English textbooks are the two major research aspects. However, the importance of teaching culture in L2 education calls for more comprehensive and in-depth studies of cultural representation in language textbooks to develop and raise learners' cultural competence.

\section{CONCLUSION}

This diachronic study aimed to review previous works of cultural representation in L2 Mandarin textbooks from 2005 to 2020 to concern methodological trends and research foci. Regards methodological trends, there are both non-empirical and empirical studies of cultural representation in L2 Mandarin textbooks, while most of them are empirical studies. Qualitative, quantitative, and mixed methods are all employed in the empirical studies in previous studies. Besides, sampled textbooks in previous works contain textbooks from different countries/regions at different levels, while most of them are elementary textbooks from China. Additionally, data of the

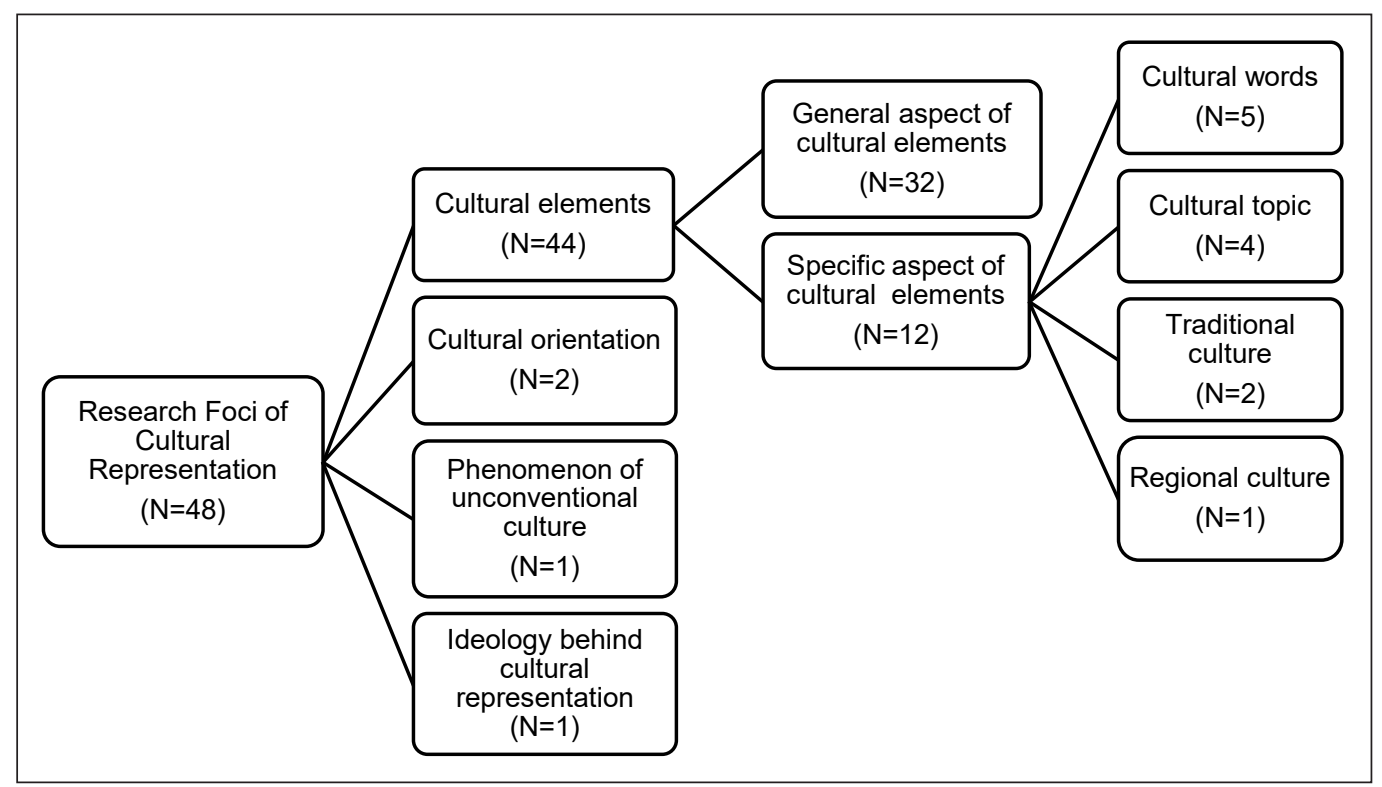

Figure 5. Research foci of cultural representation in L2 Mandarin textbooks (2005-2020) Note. $\mathrm{N}$ refers to the number of studies 
collected studies are collected from different sources such as documents, interviews, and questionnaires, while it is mainly collected from the document, especially for the empirical studies. Four methods are commonly applied for analyzing data in empirical studies: comparative analysis, content analysis, discourse analysis, and semiotic analysis. Regarding research foci, most previous works focus on examining cultural elements in L2 Mandarin textbooks, and few works analyze cultural orientation and phenomenon of unconventional culture and explore ideology behind cultural representation in textbooks. Therefore, different research methodologies are employed to fulfill the research foci. The present review draws on its findings to offer the following suggestions to researchers.

Future researchers can expand their research samples to cover different levels of more local textbooks from different countries to understand better the cultural representation in L2 Mandarin textbooks. Besides, to comprehensively and deeply explore cultural representation, it is worth considering conducting more rigorous research, investigating every corner of textbooks, collecting data from various sources, and employing complemented data analysis methods. Meanwhile, an inclusive and analytical framework for analyzing cultural content in textbooks is needed for future research. The representations of target cultures and the source and international cultures are worthwhile to concern in the analysis. In addition, most previous studies take issue with the insufficiency of cultural contents, but how different cultures are represented in L2 Mandarin textbooks are often not to be covered. Whether there are limited or biased representations in the textbooks, and if so, what are the criteria for a more balanced or desirable representation, are also less focused and unstated in literature. Future researchers may also fill the gaps in how learners and teachers perceive the cultural representations and ideologies in textbooks.

The main contribution of this review is the comprehensive survey and classification of appropriate publications on cultural representation in L2 Mandarin textbooks, in which the particular literature trends are observed, and gaps are indicated. Unfortunately, the present review is limited to the publications that CNKI, WoS, and Scopus collected. Such a limitation may therefore compromise the analysis and interpretation in the review. Furthermore, due to the diversity of topics and subtopics covered in the collected data and the space limitation, the review can only report them with exemplar works. In contrast, some works with nuance could not be included in the discussion. Besides that, other valuable sources of information such as blogs and videos made by influential researchers could also be included in future research.

\section{ACKNOWLEDGEMENT}

The authors would like to thank the reviewers and editors for their valuable comments and recommendations to improve this article. 


\section{REFERENCES}

Bewley, F. (2018). Culture and language ideology in Chinese foreign language textbooks: A thematic analysis [Unpublished master's thesis]. University of British Columbia.

Brown, H. D. (2000). Principles of language learning and teaching (4th ed.). White Plains, Addison Wesley Longman.

Burnham, J. F. (2006). Scopus database: A review. Biomedical Digital Libraries, 3, 1-9. https://doi. org/10.1186/1742-5581-3-1

Byram, M. (1997). Teaching and assessing intercultural communicative competence. Multilingual Matters.

Chan, S. F., DeWitt, D., \& Chin, H. L. (2018). The analysis of cultural and intercultural elements in Mandarin as a foreign language textbooks from selected Malaysian higher education institutes. Malaysian Online Journal of Educational Sciences, 6(1), 66-90. https://eric. ed.gov/?id=EJ1166178

Chen, G. (1992). 语言教学中的文化导入 [Cultural introduction in language teaching]. Language Teaching and Linguistic Studies, 3, 19-30.

Chen, G. (1997). 关于对外汉语课中的文化教学 问题 [Issues on cultural teaching in teaching Chinese as a foreign language]. Applied Linguistics, 1, 23-26.

Chen, H., \& Yan, F. (2017). 本土化汉语教材编 写的 “文化违和” 现象分析及对策研究 [Research on the phenomenon of unconventional culture in localized Chinese textbooks]. ScienceTechnology \& Publication, 8, 121-124. https:// doi.org/10.16510/j.cnki.kjycb.2017.08.030

Cortazzi, M., \& Jin, L. (1999). Cultural mirrors: Materials and methods in the EFL classroom. In E. Hinkel (Ed.), Culture in second language teaching and learning (pp. 196-219). Cambridge University Press.
Dong, S. (2014). 汉语教材编写的本土化特征: 基于 《汉语教科书（1954）》与通用性教材, “ 一版多本” 的比较 [Thoughts on compilation of localized Chinese textbooks: Based on the contrastive study about Chinese textbooks and single-edition-multi-version Chinese textbooks]. Overseas Chinese Education, 1, 93-100.

Fan, Q., \& Sun, J. (2018). 对外汉语教材话题的 文化因素探析 [An analysis of the cultural factors of three topics on teaching Chinese as a foreign language]. Journal of Honghe University, 16(1), 10-12. https://doi.org/10.13963/j.cnki. hhuxb.2018.01.031

Gao, Y., Li, L., \& Lü, J. (2001). Trends in research methods in applied linguistics: China and the West. English for Specific Purposes, 20(1), 1-14. https://doi.org/10.1016/S0889-4906(99)00015-0

Ge, K. (2016). 汉语文化词与文化点在中级教材、 教学中的考察 [Study on Chinese culture words and culture points in intermediate textbook, teaching and studying]. Overseas Chinese Education, 6, 805-815.

Hanban. (2014). International curriculum for Chinese language education (Revised ed.). Beijing Language and Culture University Press.

Hao, L. (2020). 对外汉语教材《桥梁》课文中 的文化项目探析 [An analysis of the cultural items in $<$ Bridge $>$ ]. Research on Transmission Competence, 4, 8, 10.

Henning, G. (1986). Quantitative methods in language acquisition research. TESOL Quarterly, 20(4), 701-708. https://doi.org/10.2307/3586520

Huang, H. (2014). 对外汉语综合课教材中的文 化项目考察分析 [Investigation and analysis of cultural items in the TCFL comprehensive textbooks]. Journal of Heilongjiang College of Education, 33(2), 57-58. http://doi.org/10.3969/j. issn.1001-7836.2014.02.024

Landis, J. R., \& Koch, G. G. (1977). The measurement of observer agreement for categorical data. 
Biometrics, 33(1), 159-174. https://doi. org/10.2307/2529310

Lei, L. (2017). 汉语教材中的文化点分布研 究: 以《汉语口语》为例 [Research about the distribution of cultural points in Chinese textbooks for foreigners: Taking $<$ Chinese Spoken Language $>$ as an example]. Journal of Xiang Yang Vocational and Technical Colledge, 16(2), 125-128.

Li, M. (2020). A systematic review of the research on Chinese character teaching and learning. Frontiers of Education in China, 15(1), 39-72. https://doi.org/10.1007/s11516-020-0003-y

Li, Q., \& Gong, X. (2015). 通用型、区域型、 语别型、国别型: 谈国际汉语教材的多元 化[The general, regional, first-language-type and country-type of textbooks of Chinese as a foreign language: An example of the pluralistic approach]. Chinese Language Learning, 1, 76-84.

Li，X. (2012). 三套国际汉语初级教材中的文化 词语编排简析 [A study of the arrangement of cultural words in three sets of international elementary Chinese textbooks]. Journal of Huaibei Normal University, 33(2), 163-165.

Li, X. (2014). 从对外汉语教材话题的选择看编写者 文化态度: 基于三部对外汉语教材话题的分析 [A study of the authors' cultural attitudes based on the topics of three TCFL textbooks]. Journal of Yunnan Normal University, 12(5), 25-32.

Li, X., \& Zang, S. (2013). 近三十年来我国对外汉 语文化教学研究综述 [A review on cultural teaching among 30 years in teaching Chinese as a second language]. Education and Teaching Research, 7, 73-77.

Liberati, A., Altman, D. G., Tetzlaff, J., Mulrow, C., Gøtzsche, P. C., Ioannidis, J. P. A., Clarke, M., Devereaux, P. J., Kleijnen, J., \& Moher, D. (2009). The PRISMA statement for reporting systematic reviews and meta-analyses of studies that evaluate health care interventions: explanation and elaboration. Journal of Clinical Epidemiology, 62(10), E1-E34. https://doi. org/10.1016/j.jclinepi.2009.06.006

Lin, W. Y., Ang, L. H., Chan, M. Y., \& Paramasivam, S. (2020). Analyzing cultural elements in L2 Mandarin textbooks for Malaysian learners. Journal of Language and Education, 6(4), 121137. https://doi.org/10.17323/ jle.2020.10332

Liu, X. (2018). 对外汉语教材 “文化话题” 选择与 中华文化走出去 [The choice of cultural topics in textbooks of teaching Chinese as a foreign language and Chinese cultural going global]. Journal of Guangxi University for Nationalities, 40(3), 200-204.

Liu, X. (2020). 基于汉语教材调查的南京地域文化 教学研究 [A study of teaching regional culture of Nanjing based on the survey of Chinese textbooks]. Sinogram Culture, 21, 162-166. https://doi.org/10.14014/j.cnki.cn11-2597/ g2.2020.21.046

Liu, Y. (2017). 初级对外汉语教材之中国文化点设 置考察分析: 以《新实用汉语课本》和《HSK 标准教程》为例 [Study on the compilation of Chinese cultural points in elementary Chinese textbooks: Taking $<$ New Practical Chinese Textbook $>$ and $<$ HSK Standard Course $>$ as examples]. Journal of An Yang Normal University, 4, 97-99.

Lu, L. (2011). 汉语教材《语言自迩集》中的 儒家思想和中国传统文化 [Confucianism and Chinese traditional culture in the Chinese textbook < Yuyan Zier Ji> ]. Journal of Beijing Xuanwu Hongqi Yeyu University, 3, 48-53.

Lu, L. (2018). 汉语国别型教材文化取向的再思 考: 基于对对外法语教材《Taxi! 》的考察 [Rethinking of cultural orientation in nationspecific Chinese course books: A case study of $<$ Taxi!>]. Journal of Yunnan Normal University, 16(2), 64-71. https://doi.org/10.16802/j.cnki. ynsddw.2018.02.009 
Lu, X., \& Cheng, Y. (2018). 对外汉语短期强化口语 教材中的文化教学点简析 [Study of cultural points in short-term intensive spoken textbooks of TCFL]. Chinese Character Culture, 110114. https://doi.org/10.14014/j.cnki.cn11-2597/ g2.2018.24.031

Ma, X., Gong, Y., Gao, X., \& Xiang, Y. (2017). The teaching of Chinese as a second or foreign language: A systematic review of the literature 2005-2015. Journal of Multilingual and Multicultural Development, 38(9), 815-830. https://doi.org/10.1080/01434632.2016.1268146

Make It Our Business. (2017, June). What does it mean to be culturally competent? http:// makeitourbusiness.ca/blog/2017/what_does_it_ mean_to_be_culturally_competent.html

Newmark, P. (1988). A textbook of translation. Prentice Hall.

Ouyang, F. (2020). 本土化视角下的国际汉语教材 文化内容对比 [A comparative study of cultural content in international Chinese textbooks from the perspective of localization]. Journal of Liaoning Educational Administration Institute, 6, 103-107. https://doi.org/10.13972/j.cnki.cn21$1500 / \mathrm{g} 4.2020 .06 .024$

Ouyang, F., \& Zhou, X. (2016). 跨文化视角下的中 美汉语教材文化呈现比较 [A contrastive study of cultural presentation in Chinese and American textbooks of teaching Chinese as a foreign language from an intercultural perspective]. TCSOL Studies, 1, 78-84. https://doi. org/10.16131/j.cnki.cn44-1669/g4.2016.01.009

Ran, L. (2011). 融中国文化于汉语教材之中: 关于 汉语教材编写的一点意见 [Integrating Chinese culture into Chinese textbooks: Suggestions on compiling Chinese textbooks]. Periodicals of Humanities, 6, 120-127.

Shen, Y. (2019). A literature review on studies of cultural contents in English textbooks for Chinese senior high school from 2003 to 2018.
Open Journal of Social Sciences, 07(05), 26-36. https://doi.org/10.4236/jss.2019.75002

Shu, D., \& Zhuang, Z. (2008). Modern foreign language teaching: Theory, practice and methods. Shanghai Foreign Language Education Press.

Spencer-Oatey, H. (2012). What is culture? A compilation of quotations. GlobalPAD core concepts. GlobalPAD Open House. http://www. warwick.ac.uk/globalpadintercultural

Steinhardt, I., Schneijderberg, C., Götze, N., Baumann, J., \& Krücken, G. (2017). Mapping the quality assurance of teaching and learning in higher education: The emergence of a specialty? Higher Education, 74(2), 221-237. https:/doi. org/10.1007/s10734-016-0045-5

van Dijk, T. (2006). Ideology and discourse analysis. Journal of Political Ideologies, 11, 115-140.

Wang, D. (2016). Learning or becoming: Ideology and national identity in textbooks for international learners of Chinese. Cogent Education, 3(1), 1-16. https://doi.org/10.1080/233118 6X.2016.1140361

Wang, J. (2016). 意大利国别化汉语教材中的文 化因素研究: 以《当代中文》和《意大利人 学汉语》为例 [Cultural factors in countryspecific textbooks: A case study of $<$ II Cinese Per Gli Italiani $>$ and $<$ Cinese Contemporaneo $>$ ]. Journal of Yunnan Normal University, 14(5), 12-16. https://doi.org/10.16802/j.cnki. ynsddw.2016.05.004

Wang, S. (2013). 三套对外汉语教材中交际文化项 目分析 [Analysis of communicative cultural elements in three sets of TCSL textbooks]. Proceedings of Beijing Postgraduate Forum on Teaching Chinese as a Foreign Language, 303-312.

Wang, Y. (2016). 试析国际汉语教材对文化因素 的融入: 以《环球汉语1》Cultural Bits为例 [Analysis of integration of cultural factors in 
international Chinese textbooks: Taking $<$ Global Chinese $1>$ (cultural bits) as an example]. Chinese Journal of Education, 11, 153-154, 163.

Weninger, C. (2018). Textbook analysis. In C. A. Chapelle (Ed.), The encyclopedia of applied linguistics (pp. 1-8). Hoboken, Wiley \& Sons. https://doi.org/10.1002/9781405198431. wbeal1489

Weninger, C., \& Kiss, T. (2015). Analyzing culture in foreign/second languge textbooks: Methodological and conceptual issues. In X. Curdt-Christiansen \& C. Weninger (Eds.), Language, ideology and education: The politics of textbooks in language education (pp. 50-66). Routledge. https://doi. org/10.4324/9781315814223

Xin, P. (2015). 初级汉语教材中文化匹配度研究: 以 中、美、日六部教材为例 [Study of matching degree between cultual content and language materials in elementary Chinese textbooks]. Journal of Jilin Normal University (Humanities \& Social Science Edition), 1, 80-86.

Xiong, T., \& Peng, Y. (2020). Representing culture in Chinese as a second language textbooks: A critical social semiotic approach. Language, Culture and Curriculum, 1-20. https://doi.org/1 0.1080/07908318.2020.1797079

Yang, J. (2014). 国际汉语教材文化点的选取与 编排 [How to select and arrange the Chinese culture points for international Chinese teaching materials]. Digital Chinese Language Teaching, 178-184.
Yang, Y., Zhao, X., \& Xu, M. (2018). 对外汉语教 材中的传统体育文化内容探析 [Research on traditional sports culture in Chinese foreign language teaching materials]. Jounal of Harbin Sport University, 36(2), 80-89.

Zhang, H. (2011). “话题” 的选取及 “文化项 目” 的兼容: 中级汉语教材问题研究 [The selection of topics and the compatibility of cultural programes: A research of intermediate Chinese textbooks]. Journal of Suzhou Colledge of Education, 28(6), 32-35.

Zhang, Y. (2009). 浅议对外汉语教材中注释对文化 因素的介绍 [Analysis of notes for introducing cultural factors in TCFL textbooks]. Business Culture, 4, 205.

Zhang, Z. (1984). 汉语个别教学及其教材 [Individualized instruction of Chinese and teaching materials]. Language Teaching and Linguistic Studies, 57-67.

Zhang, Z. (1990). 试议交际文化和知识文化 [Communicative culture and knowledge culture]. Language Teaching and Linguistic Studies, 3, 15-32.

Zhao, M. (2010). 对外汉语中级教材中文化词 语收词的定量研究 [A quantitative study of cultural words in TCFL intermediate textbooks]. Overseas Chinese Education, 1, 9-15.

Zhen, Q. (2018). 内地、香港与台湾对外汉语教材 中国文化项目的比较研究[A comparative study of Chinese cultural items in TCFL textbooks from mainland, Hong Kong and Taiwan]. Journal of Chinese Multimedia and Network Instruction, 54-55. 